\title{
Harran Ovası Organik Tarım Koşullarında Üretimi Yapılan Bazı Pamuk (Gossypium hirsutum L.) Çeşitlerinde Farklı Organik Gübre Uygulamalarının Gün Sayısı ve Gün-Derece Değerlerine Etkisi
}

\author{
Cevher ilhan CEVHERi ${ }^{1 *}$, Ahmet YILMAZ ${ }^{2}$ \\ ${ }^{1}$ Harran Üniversitesi, Akçakale MYO, Organik Tarım Bölümü, Şanlıurfa, Türkiye. \\ ${ }^{2}$ Harran Üniversitesi, Ziraat Fakültesi, Tarla Bitkileri Bölümü, Şanlıurfa, Türkiye. \\ *Sorumlu yazar: icevheri@harran.edu.tr
}

\begin{abstract}
Öz
İklim değerleri içinde sıcaklık, pamuk bitkisinin çimlenme, koza oluşumu ve hasat sürecine kadar büyüme, gelişme gibi bütün fizyolojik dönemleri etkileyen en önemli faktörlerden birisidir. Bu çalışma, Harran Ovası organik tarım koşullarında, 2014 ve 2015 yıllarında beş farklı organik gübre uygulamaları (Biofarm, Güvercin, Biofarm + Mikrobiyal, Güvercin + Mikrobiyal ve kontrol) ile yürütülmüştür. Araştırma BA-119 ve Candia pamuk çeşitlerinin fizyolojik gelişme sürelerine (gün ve gün-derece), farklı organik gübre uygulamalarının etkilerinin belirlenmesi amacıyla yürütülmüştür. Çalışmadan elde edilen sonuçlara göre; ilk gerçek yaprak, taraklanma, çiçeklenme, koza açımı ve hasat olgunluğu evrelerine ait en düşük "gün" değerleri ortalamaları, incelenen özellikler yönünden BA-119 çeşidine ait olup sırasıyla; $15.94,37.74,61.95,114.35$ ve 131.05 gün olarak elde edilmiştir. BA-119 çeşidine ait "gün-derece" değerleri ortalaması ise; $107.60,317.31,631.17,1463.04$ ve $1694.76{ }^{\circ} \mathrm{C}$ şeklindedir. Ayrıca, kullanılan organik gübrelere göre incelenen özellikler yönünden, yukarıda belirtilen karakterlere ait en düşük "gün" değerleri sırasıyla; Güvercin + Mikrobiyal gübre 17.12, Güvercin gübresi 44.50, Biofarm gübresi 64.62, Biofarm gübresi 117.74 ve kontrol 133.37; "gün-derece" değerleri yönünden Biofarm + Mikrobiyal gübre 116.50, Biofarm gübresi 400.10, Biofarm gübresi 685.44, Biofarm gübresi 1530.46 ve Biofarm gübresi $1749.30{ }^{\circ} \mathrm{C}$ gübre uygulamalarından elde edilmiştir. Çeşit-gübre interaksiyonu incelendiğinde incelenen özellikler yönünden önemli bulunmamıştır.
\end{abstract}

Anahtar Kelimeler: Organik, Pamuk, Gübre, Sıcaklık, Periyot

\section{The Effects of Different Organic Fertilizer Applications on Day Number and Day- Degree Value of Some (Gossypium hirsutum L.) Cotton Varieties, Grown as Organic Agriculture Under Harran Plain Conditions}

\begin{abstract}
The temperature in climate values, is one of the most important factor affecting all physiological periods such as germination of cotton seeds, boll formation and growth, development until the harvest. This study has been performed to examine the effect of BA-119 and Candia cotton varieties belonging to Gossypium hirsutum L, with five different fertilizer applications (Biofarm, Pigeon Manure, Biofarm + Microbial Manure, Pigeons Manure + Microbial Manure and Control) on heat amount what they need for different physiological development period under Harran Plain Organic Farming conditions during 2014 and 2015. This study was carried out to determine the effects of different organic manures applies on physiological development periods (days and days-degrees) on BA-119 and Candia cotton varieties. According to our results; the lowest day values that belong to the phases of first real leaf, squaring, flowering, boll opening and harvest maturation in BA-119 species are respectively as follows; 15.94, $37.74,61.95,114.35$ and 131.05 . The lowest day-degree average for BA-119 species is 107.60, 317.31, 631.17, 1463.04 and 1694.76. In addition, the lowest day values, regarding the organic fertilizer used are 17.12 (Pigeon Manure + Microbial Manure), 44.50 (Pigeon Manure), 64.62 (Biofarm), 117.74 (Biofarm)
\end{abstract}


and 133.37 (control applications). The day-degree averages are 116.50 (Biofarm + microbial fertilizer), 400.10 (Biofarm), 685.44 (Biofarm), 1530.46 (Biofarm) and 1749.30 (Biofarm fertilizer). On the other hand, the interactions between species and fertilizers were in significant.

Keywords: Organic, Cotton, Fertilizer, Temperature, Period

\section{Giriş}

Pamuk tarımında birim alandan maksimum ürün alabilmek için üreticiler üretim sezonu boyunca birçok önemli kararlar almak zorundadırlar. Bu kararlar; toprak işleme, ekim zamanı, çeşit seçimi, gübre kullanımı, ekim sıklığı, sulama zamanı, hastalık ve zararlılarla mücadele ve bazı bitki gelişim düzenleyicilerin kullanımıdır. Bu kararlar alınırken bazı faktörler dikkate alınmaktadır. Bu faktörlerden en önemlisi olan sıcaklık, tamamen yetiştiricinin kontrolü dışındadır. Pamuk yetiştirme dönemi boyunca günlük maksimum ve minimum sıcaklıklar, sıcaklığın niteliğini ortaya koymaktadır. Diğer bir ifade ile gelişme periyodu içerisinde gerçekleşen günlük maksimum ve minimum sıcaklıklar pamuk bitkisinin gelişme dönemlerinin uzunluklarını tayin etmektedir (Özbek ve ark., 2000). Pamuktaki gelişme, genetik yapı ve çevresel faktörlerce kontrol edilmektedir. Çevresel faktörler içerisinde sıcaklık, pamuk büyüme ve gelişmesini kontrol eden temel faktörlerden birisidir. Pamuk bitkisinin gelişme dönemleri için ihtiyaç duyduğu gündüz ve gece sıcaklık dereceleri farklıdır (Reddy ve ark., 1991). Pamuk bitkisinin vejetasyon süresince belli evreler vardır. Bu evreler; ilk gerçek yaprak teşekkülü, taraklanmanın başlaması, çiçeklenme, döllenme, koza teşekkülü kozanın olgunlaşması, büyüme ve gelişmenin duraklaması süreçleridir. Bütün bu süreçlerde çevresel faktörlerin değişkenlik arz etmesi sıcaklık ve diğer iklim şartlarının sürekli bir değişim içinde olması, bazen fizyolojik gelişim açısından olumlu bir süreç olmasına rağmen, bazen de olumsuz durumlara ortaya çıkmasına neden olmaktadır. Sıcaklığın düşük olması vejetasyon sürecinin uzaması ve ürün kalitesinde düşüş ve hasadın uzaması gibi sorunları beraberinde getirmektedir. Ayrıca sıcaklığın çok yüksek olması da vejetasyon sürecinin kısalması, kuraklık ve fizyolojik gelişimin tam gerçekleşmemesi anlamına gelmektedir. Buna rağmen sıcaklığın çok düşük ve yüksek olması bitkinin fizyolojik olarak gelişiminin tam gerçekleşmesi konusunda ciddi sıkıntılar oluşturmaktadır. Özellikle fotosentez, organik madde üretimi, çiçek oluşumunda aksama, döllenme biyolojisinde düşüş, lif verimi ve kalitesinde düşüş gibi sorunlar getirmektedir.

Pamuk bitkisi gelişme dönemlerinden (ilk gerçek yaprak dönemi, taraklanma, çiçeklenme, koza açma başlangıcı ve hasat olgunluğu) birisini tamamlayıp diğerine geçebilmesi, o dönem için gerekli sıcaklık birikimini sağlaması ile mümkündür (Özbek ve ark., 2000). Pamuğun ilk gelişme (ana sap uzaması, yaprak alanı gelişimi ve biomass üretimi), taraklanma, çiçeklenme ve koza gelişim dönemleri için en uygun gündüz/gece sıcaklık değerleri, sırasıyla 30/22 ${ }^{\circ} C^{\prime}$ dir (Reddy ve ark., 1992). Bitkideki gelişim süresini normal takvim günü ile belirlemek mümkün olmadığını yapılan çalışmalar göstermiştir. Bu yüzden "fizyolojik gün" ya da "gün-derece" gibi değerler ortaya koyma zorunluluğu doğmaktadır (Haley ve Bazelet, 1989; Anonim, 1998). Büyüme gün-derece hesaplaması için birçok yol bulunmaktadır. $\mathrm{Bu}$ hesaplamada, bitkilerin günlük ortalama 
sıcaklıktan bitkinin fotosentez yapabilmesi için gerekli minimum sıcaklık (eşik sıcaklığı) olan $15.5^{\circ} \mathrm{C}$ çıkarılarak elde edilmektedir.

Bu çalışma Harran Ovası organik tarım koşullarında (Gossypium hirsutum L.) türüne ait iki pamuk çeşidinin, farklı organik ve mikrobiyal gübreleme sonucunda bitkinin gelişim sürecine gün sayısı ve gün derece değerleri açısından etkisini görmek amacıyla planlanmış ve yürütülmüştür.

\section{Materyal ve Metot}

Bu araştırma, Harran Ovası organik tarım koşullarında 2014 ve 2015 yıllarında tesadüf blokları bölünmüş parseller deneme desenine göre, dört tekerrürlü olarak yürütülmüştür. Deneme parsel uzunlukları 12 metre, parsel genişlikleri 2.8 metre ve parseller arasında 3 metre boşluk olacak şekilde planlanmıştır. Ekim zamanları 2014 yılında 05 Mayıs ve 2015 yılında 28 Nisan tarihlerinde yapılmış olup, ana parselleri çeşitler, alt parselleri organik ve mikrobiyal gübreler oluşturmuştur. Gübre uygulamaları; Biofarm (katı çiftlik gübresi), Güvercin gübresi, Biofarm gübresi + Mikrobiyal gübre, Güvercin gübresi + Mikrobiyal gübre ve Kontrol parselleri şeklindedir. Denemede kullandığımı gübrelerin içeriklerine baktığımızda Biofarm gübresi; Büyükbaş hayvan gübresi ve bitkisel protein kaynakların fermantasyonu yöntemiyle üretilmiştir. Toprağın fiziksel yapısını düzelten, toprağı bitki besin maddeleri ve humusça zenginleştiren bir gübredir. Biofarm gübresinin içeriğine baktığımızda, organik madde oranı \%50, toplam azot (N) \%2, Organik Azot $(\mathrm{N}) \% 1.6$, toplam fosfor $\mathrm{P}_{2} \mathrm{O}_{5}$ $\% 2$, suda çözünür potasyum $\mathrm{K}_{2} \mathrm{O} \% 2$, maksimum nem \%20, C/N 9-12, pH aralığı 78 dolaylarındadır (Anonim, 2016a). Çalışmada kullanılan Güvercin gübresinin, \% 25 organik madde, \% 6.24 toplam azot, \%
1.19 fosfor $\left(\mathrm{P}_{2} \mathrm{O}_{5}\right)$ ve \% 1,61 potasyum $\left(\mathrm{K}_{2} \mathrm{O}\right)$ içerdiği belirlenmiştir. Mikrobiyal (Bakteri) gübresi; Bacillus subtilis ve Paenibacillus azotofixans bakterileri içermekte olup, toprak bünyesinde bulunan azot ve fosforun yarayışı konuma gelmesini sağlamaktadır (Anonim, 2016b). Denemede BA-119 ve Candia pamuk çeşitleri kullanımıştır. BA-119 çeşidi erkenci çeşit olup, orta boylu, bölgeye adapte olmuş, makineli hasada uygun verimli bir çeşittir. Candia çeşidi ise geç̧̧i, orta boylu, bölgeye adapte olmuş, makineli hasada uygun, verimli bir çeşittir. Deneme alanın toprakları killi tınlı yapıya sahip olup, toplam tuz oranı \% 1.36, kireç oranı $\left(\mathrm{CaCO}_{3}\right) \% 26.9$, organik madde oranı \% 1.11 ve toprak reaksiyonu $\mathrm{pH}$ :7.82 olup biraz alkali yapıya sahip topraklardır. İki yılda deneme aynı yere kurulmuş olup çakılı deneme formatında yürütülmüştür. Toprak hazırlığı, kasım ayından sonra pullukla $25 \mathrm{~cm}$ derinliğinde sürülmüş, ilkbaharda mart ayında kültivatörle ikinci sürüm yapılmıştır. Nisanın ilk haftasında toprak tava geldiğinde gobledisk çekilmiş hemen ardından Biofarm ve güvercin gübresi uygulanarak toprağa karıştırılmıştır. Biofarm katı çiftlik gübresi $200 \mathrm{~kg} \mathrm{da}^{-1}$ ve güvercin gübresi $100 \mathrm{~kg} \mathrm{da}^{-1}$ miktarında toprağa verilmiştir. Mikrobiyal (Bakteri) gübreler ise bitkiler $15 \mathrm{~cm}$ uzunluğuna geldiğinde, taraklanma dönemi ve koza oluşum döneminde bütün bitkiye sırt pompasıyla bitkinin kolayca absorbe edebilmesi için akşam saatlerinde 1 I bakteri karışımı gübre $100^{-1}$ | su dozunda püskürtülmüştür. El ve traktör çapası olmak üzere toplam $6 \mathrm{kez}$ yabancı otlara karşı çapalama işlemi uygulanmıştır. Denemede, damla sulama sistemi kullanılmış ve toplam 7 kez sulanmıştır. Pamuğun yetişme süresi boyunca; Yaprak biti (Aphis gossypii), Trips (Trips tabaccei), Yaprak piresi (Empoasca spp.), Kırmızı örümcek (Tetranychus spp.), 
Beyazsinek (Bemicia tabaci) ve Yeşil kurt (Heliothi sarmigera) zararlılarına karşı, organik tarım mevzuatına uygun ilaçlar uygulanmıştır. Bu amaçla arap sabunu (3 kg $100^{-1}$ | su) ve ispirto (600 gr $100^{-1}$ | su) karışımı uygulanmıştır. Ayrıca yaprak biti, trips, beyazsinek ve kırmızı örümceğe karşı, Neem ağacından elde edilen Azadirachta indica içerikli $300 \mathrm{cc} 100^{-1}$ I su dozunda üç kez bütün bitki yüzeyini kaplayacak şekilde günün serin saatlerinde zararlı yoğunluğuna göre uygulanmıştır.

Pamuk yetişme süresinin sonunda, iki çeşit için farklı organik gübrelerle tesis edilen parsellerin iki başından 1'er metre atılmış ve ortadaki iki sıra (toplam $14 \mathrm{~m}^{2}$ ) hasat alanı olarak belirlenmiştir. Hasat, 2014 yılında, 25.09.2014 ve 09.10.2015 tarihlerinde; 2015 yllında, 20.09.2015 ve 05.10.2015 tarihlerinde iki kez elle hasat edilmiştir. Pamuk yetişme dönemine ait iklim verileri, Şanlıurfa Meteoroloji ì Müdürlüğünden alınmış olup, Akçakale'de bulunan rasathane deneme alanına yaklaşık $1 \mathrm{~km}$ uzaklıktadır. Pamuk yetişme dönemi olan nisan-ekim ayları arasında 2014, 2015 ve uzun yıllar iklim verileri Çizelge 1 'de verilmiştir. Çizelge 1 'den; Pamuğun yetiştiği nisan-ekim ayları arasında ortalama sıcaklığın 2014 yılı Nisan ayında $18.3^{\circ} \mathrm{C}$, Temmuz ayında $31.5^{\circ} \mathrm{C}$ ve 2015 yılı Nisan ayında $15.5^{\circ} \mathrm{C}$, Temmuz ayında $32.2{ }^{\circ} \mathrm{C}$ olduğu; En yüksek sıcaklığın 2014 yılı Nisan ayında $26.1{ }^{\circ} \mathrm{C}$, Temmuz ayında $40.2{ }^{\circ} \mathrm{C}$ ve 2015 yılı Nisan ayında $23.0{ }^{\circ} \mathrm{C}$, Temmuz ayında $40.7{ }^{\circ} \mathrm{C}$ olduğu; En düşük sıcaklığın 2014 yılı Nisan ayında $11{ }^{\circ} \mathrm{C}$, Temmuz ayında $22.6{ }^{\circ} \mathrm{C}$ ve 2015 yılı Nisan ayında $8.5{ }^{\circ} \mathrm{C}$, Temmuz ayında $23.1{ }^{\circ} \mathrm{C}$ olduğu saptanmıştır.

Pamuk bitkisinde ilk gerçek yaprak (1m sıra üzerinde, 5-10 $\mathrm{mm}$ büyüklüğünde 1 adet ilk gerçek yaprak), taraklanma başlangıcı (1 $\mathrm{m}$ sıra üzerinde, $5 \mathrm{~mm}$ büyüklüğünde 1 adet tarak), çiçeklenme başlangıcı (1 $\mathrm{m}$ sıra üzerinde, 1 adet çiçek), koza açma başlangıcı (1 $\mathrm{m}$ sıra üzerinde, 1adet açmış koza) ve hasat olgunluğu (1 m sıra üzerinde, kozaların ortalama \% 60'ının açtığı dönem) dönemleri için gerekli gün sayıları ve gün-derece üniteleri hesaplanmıştır (Özbek ve ark., 2000). Bu dönemlere ilişkin gün-derece ünitesi değerleri, günlük maksimum sıcaklık ile minimum sıcaklık ortalamalarının ikiye bölünerek, pamuk bitkisinin minimum gelişme seviyesi olarak kabul edilen $15.5^{\circ} \mathrm{C}^{\prime}$ nin çıkarılması sonucu hesaplanmıştır. Elde edilen gün sayıları ve gün-derece ünitesi değerleri, JUMP istatistik paket programı ile varyans analizleri yapılmış, önemlilik seviyeleri LSD testine göre gruplandırılmıştır.

\section{Araştırma Bulguları ve Tartışma}

Çizelge 2'den, çeşitlerde iki yıl ortalamasına göre kütlü pamuk veriminin ( $\mathrm{kg}$ $\mathrm{da}^{-1}$ ) 389.18 (Candia) ile $399.80 \mathrm{~kg} \mathrm{da}^{-1}$ (BA119) arasında olduğu en yüksek kütlü pamuk veriminin BA-119 çeşidinden elde edildiği görülmektedir. Denemede uygulanan organik gübrelere göre kütlü pamuk veriminin (kg da ${ }^{-1}$ ) 257.63 (kontrol) ile $451.82 \mathrm{~kg} \mathrm{da}^{-1}$ (güvercin gübresi + mikrobiyal gübre) arasında değiştiği, en yüksek kütlü veriminin güvercin gübresi + mikrobiyal gübre uygulamasından elde edildiği görülmüştür. Bu bulgulara göre; en yüksek kütlü pamuk verimleri her iki yılda da Çeşit $\mathrm{x}$ gübre interaksiyonuna bakıldığında $463.14 \mathrm{~kg} \mathrm{da}^{-1}$ verim ile BA-119 $\mathrm{x}$ (güvercin gübresi + mikrobiyal gübre) interaksiyonundan elde edildiği görülmüştür. $\mathrm{Bu}$ sonuçlarda görüldüğü gibi güvercin gübresinin mikrobiyal gübre ile karışımı sonucu diğer organik gübre uygulamalarına göre birim alandan daha çok kütlü pamuk kazanılmasına yardımcı olmuştur. Fakat kullanılan organik ve mikrobiyolojik gübreler, toprağı iyileştirmesi, mikrobiyolojik etkinliği 
artırması, toprakta ve bitki çevresinde azaltması verimin artışında önemli bir bulunan hastalık ve zararlı etkinliğini parametre olmuştur.

Çizelge 1. 2014 ve 2015 Yıllarında Denemenin Yürütüldüğü Aylara Ait Bazı İklim Verileri ve Uzun Yıllar Ortalaması Verileri (Anonim, 2016c)

Table 1. Some climate datas and long annual average datas belonging the months in which trial executed in 2014 and 2015 (Anonim, 2016c)

\begin{tabular}{|c|c|c|c|c|}
\hline $\begin{array}{l}\text { Aylar } \\
\text { Months }\end{array}$ & $\begin{array}{l}\text { Yıllar } \\
\text { Years }\end{array}$ & $\begin{array}{c}\text { Ortalama Sıcaklık }\left({ }^{\circ} \mathrm{C}\right) \\
\text { Average Temp. }\left({ }^{\circ} \mathrm{C}\right)\end{array}$ & $\begin{array}{c}\text { En Yüksek Sıcaklık }\left({ }^{\circ} \mathrm{C}\right) \\
\text { Highest Temp. }\left({ }^{\circ} \mathrm{C}\right)\end{array}$ & $\begin{array}{c}\text { En Düşük Sıcaklık }\left({ }^{\circ} \mathrm{C}\right) \\
\text { Lowest Temp. }\left({ }^{\circ} \mathrm{C}\right)\end{array}$ \\
\hline \multirow{2}{*}{$\begin{array}{l}\text { Nisan } \\
\text { April }\end{array}$} & 2014 & 18.3 & 26.1 & 11.0 \\
\hline & 2015 & 15.5 & 23.0 & 8.5 \\
\hline \multirow{2}{*}{$\begin{array}{l}\text { Mayıs } \\
\text { May }\end{array}$} & 2014 & 23.6 & 31.7 & 15.1 \\
\hline & 2015 & 23.3 & 31.3 & 15.1 \\
\hline \multirow{2}{*}{$\begin{array}{l}\text { Haziran } \\
\text { June }\end{array}$} & 2014 & 28.1 & 35.7 & 19.3 \\
\hline & 2015 & 27.6 & 35.2 & 18.8 \\
\hline \multirow{2}{*}{$\begin{array}{l}\text { Temmuz } \\
\text { July }\end{array}$} & 2014 & 31.5 & 40.2 & 22.6 \\
\hline & 2015 & 32.2 & 40.7 & 23.1 \\
\hline \multirow{2}{*}{$\begin{array}{l}\text { Ağustos } \\
\text { August }\end{array}$} & 2014 & 31.1 & 40.4 & 22.1 \\
\hline & 2015 & 30.9 & 39.6 & 22.3 \\
\hline \multirow{2}{*}{$\begin{array}{l}\text { Eylül } \\
\text { September }\end{array}$} & 2014 & 26.0 & 33.6 & 18.4 \\
\hline & 2015 & 28.3 & 37.1 & 19.7 \\
\hline \multirow{2}{*}{$\begin{array}{l}\text { Ekim } \\
\text { October }\end{array}$} & 2014 & 19.5 & 26.8 & 13.2 \\
\hline & 2015 & 21.3 & 28.9 & 14.9 \\
\hline
\end{tabular}

Çizelge 2. Denemede kullanılan pamuk çeşitlerine ve organik gübrelere ilişkin ortalama kütlü pamuk verimi $\left(\mathrm{kg} \mathrm{da}^{-1}\right)$ ile kütlü pamuk verimine ilişkin çeşit $\mathrm{x}$ gübre interaksiyonu

Table 2. Variety manure interaction regarding yield of cotton unseed and average yield of cotton unseed $\left(\mathrm{kg} \mathrm{da}^{-1}\right)$ regarding organic manure and cotton types used in trial

\begin{tabular}{|c|c|c|c|}
\hline \multirow[t]{3}{*}{$\begin{array}{l}\text { Organik gübre } \\
\text { Organic manure }\end{array}$} & \multicolumn{3}{|c|}{$\begin{array}{c}\text { Kütlü pamuk verimi }\left(\mathrm{kg} \mathrm{da}^{-1}\right) \\
\text { The seed cotton yield }\end{array}$} \\
\hline & \multicolumn{3}{|c|}{$\begin{array}{l}\text { Çeşitler } \\
\text { Varieties }\end{array}$} \\
\hline & BA-119 & Candia & $\begin{array}{l}\text { Ortalama } \\
\text { Average }\end{array}$ \\
\hline $\begin{array}{l}\text { 1.Biofarm gübresi } \\
\text { 1.Biofarm manure }\end{array}$ & 453.87 & 421.81 & 437.84B \\
\hline $\begin{array}{l}\text { 2.Güvercin gübresi } \\
\text { 2.Pigeon manure }\end{array}$ & 415.62 & 415.44 & $415.53 C$ \\
\hline $\begin{array}{l}\text { 3.Biofarm gübresi + Mikrobiyal gübre } \\
\text { 3.Biofarm manure + Microbial manure }\end{array}$ & 415.90 & 403.32 & 406.09C \\
\hline $\begin{array}{l}\text { 4.Güvercin gübresi + Mikrobiyal gübre } \\
\text { 4.Pigeon manure + Microbial manure }\end{array}$ & 463.14 & 440.51 & $451.82 \mathrm{~A}$ \\
\hline $\begin{array}{l}\text { 5. Kontrol } \\
\text { 5.Control }\end{array}$ & 250.45 & 264.82 & 257.63D \\
\hline $\begin{array}{l}\text { Ortalama } \\
\text { Average }\end{array}$ & 399.80 & 389.18 & 394.49 \\
\hline LSD(\%5) & \multicolumn{3}{|c|}{12.47 (Çeşit) (Variety), 13.69 (Gübre) (Manure) 23.35} \\
\hline CV(\%) & \multicolumn{3}{|c|}{5.73} \\
\hline
\end{tabular}

$\left.\left({ }^{*}\right): 0.05 ;{ }^{* *}\right): 0.01$ düzeyinde önemli fark bulunmaktadır. 
Çizelge 3'ten çeşitlere göre ekim ile ilk gerçek yaprak dönemi, taraklanma başlangıCl, çiçeklenme başlangıcı, koza açma başlangıcı ve hasat olgunluğuna ulaşmak için gün değerleri, iki yıl ortalamasına göre çeşitler (BA-119 ve Candia) yönünden 15.94$19.56, \quad 37.74-52.70,61.95-70.82,114.35-$ 126.50 ve $131.05-142.07$ arasında değişen gün sayısına ihtiyaç duydukları anlaşılmaktadır. Bu gelişme dönemlerinde, BA-119 çeşidi daha erkenci ve daha az gün sayısına intiyaç duymuştur. Çizelge 3'ten denemede uygulanan organik gübrelere göre (biofarm, güvercin, biofarm + mikrobiyal, güvercin + mikrobiyal gübreleri ve kontrol uygulaması) ekim ile ilk gerçek yaprak dönemi, taraklanma başlangıcl, çiçeklenme başlangıcı, koza açma başlangıcı ve hasat olgunluğuna ulaşmak için gün değerleri, iki yıl ortalamasına göre, 17.12 (Güvercin gübresi + mikrobiyal gübre) ile 19.93 (Kontrol), 44.50 (güvercin gübresi) ile 47.12 (kontrol), 65.50 (biofarm gübresi) ile 68.18 (kontrol), 119.37 (biofarm gübresi) ile 122.00 (güvercin gübresi + mikrobiyal gübre) ve 135.37 (biofarm gübresi) ile 137.68 (güvercin gübresi + mikrobiyal gübre) arasında değiştiği anlaşılmaktadır. Ekim-ilk gerçek yaprak dönemi döneminde güvercin gübresi + mikrobiyal gübre uygulamasında pamuklar daha erken ilk yaprak oluşumu peryoduna ulaştıkları görülmüştür. Güvercin gübresi + mikrobiyal gübre uygulaması, ilk yaprak oluşum döneminde bitkide fizyolojik olarak erkencilik sağlanmıştır. Ekim- ilk tarak teşekkülü döneminde güvercin gübresinin erkenciliği sağladığı görülmüştür. Yine biofarm gübresinin, ekim-ilk çiçeklenme, ekim-ilk koza teşekkülü ve ekim-hasat olgunluğu döneminde erkenciliği sağladığı görülmüştür (Çizelge 3).

Çizelge 4'ten ekim ile ilk gerçek yaprak dönemi, taraklanma başlangıcl, çiçeklenme başlangıcı, koza açma başlangıcı ve hasat olgunluğuna uluşmak için gün-derece değerleri, iki yıl ortalamasına göre çeşitler (BA-119 ve Candia) yönünden; 107.60136.58, 317.31-498.54, 631.17-765.49, 1463.04-1625.19 ve $1694.76-1832.77 \quad\left({ }^{\circ} \mathrm{C}\right)$ gün-derece miktarına intiyaç duydukları anlaşılmaktadır. Bu geliş̧me dönemlerinde, BA-119 çeşidi daha erkenci ve daha az gündereceye $\left({ }^{\circ} \mathrm{C}\right)$ ihtiyaç duymuştur. Buna karşın Candia çeşidi ise BA-119'dan daha geçci ve daha fazla gün-derece değerlerine $\left({ }^{\circ} \mathrm{C}\right)$ intiyaç duymuştur. Dolayısı ile çeşitler arasında incelenen özellikler yönünden istatistiksel farklılık saptanmıştır.

Çizelge 4'ten denemede uygulanan organik gübrelere göre (biofarm, güvercin, biofarm + mikrobiyal, güvercin + mikrobiyal gübreleri ve kontrol uygulaması) ekim ile ilk gerçek yaprak dönemi, taraklanma başlangıcı, çiçeklenme başlangıcı, koza açma başlangıcı ve hasat olgunluğuna ulaşmak için gün-derece $\left({ }^{\circ} \mathrm{C}\right)$ değerleri, iki yıl ortalamasına göre, 116.69 (güvercin gübresi + mikrobiyal gübre) ile $140.30{ }^{\circ} \mathrm{C}$ (kontrol), 400.10 (biofarm gübresi) ile $431.41{ }^{\circ} \mathrm{C}$ (kontrol), 685.44 (biofarm gübresi) ile $724.16{ }^{\circ} \mathrm{C}$ (kontrol), 1530.46 (biofarm gübresi) ile $1565.66{ }^{\circ} \mathrm{C}$ (güvercin gübresi + mikrobiyal gübre) ve 1749.30 (biofarm gübresi) ile $1779.15{ }^{\circ} \mathrm{C}$ (güvercin gübresi + mikrobiyal gübre) arasında değiştiği saptanmıştır. Ekimilk gerçek yaprak dönemi döneminde güvercin gübresi + mikrobiyal gübre uygulamasında pamuklar daha düşük toplam sıcaklık $\left({ }^{\circ} \mathrm{C}\right)$ değeri ile ilk yaprak oluşumu peryoduna ulaştıkları görülmüştür. Güvercin gübresi + mikrobiyal gübre uygulaması sayısında ilk yaprak oluşum döneminde bitkide fizyolojik olarak erkencilik sağlanmıştır. Yine biofarm gübresinin, ekimilk tarak teşekkülü, ekim-ilk ilk çiçek açma, ekim-ilk koza teşekkülü ve ekim-hasat 
olgunluğu dönemlerinde erkenciliği sağladığı görülmüştür. Bu sonuçlar, güvercin gübresi + mikrobiyal gübre uygulamasının topraktaki azot miktarını arttırarak fazla azotun da vejetatif dönemi uzattığı sonucuna varılabilir. Diğer yandan kontrol parsellerinde de geçcilik görülmüştür. Gübre uygulamaları bitkinin vejetatif gelişme için ihtiyaç duyduğu azot, generatif döneme geçmesi için gerekli olan fosforu ve kalite için gerekli olan potasyumu dengeli bir şekilde bitkiye sağlayarak daha kısa sürede koza açma dönemine geçmeyi sağladığı söylenebilir. Bu sonuçlar, mikrobiyal gübrelerdeki bakterilerin bitkinin fizyolojik gelişimine önemli katkı sağladığını ortaya koymaktadır. Yine biofarm gübresinin tek başına kullanıldığı parsellerde bitkinin vejetatif ve generatif dönemlerinde erkenciliğin sağlandığı saptanmıştır (Çizelge 4). 
Çizelge 3. Denemede kullanılan pamuk çeşitlerine ve organik gübrelere ilişkin ortalama gün sayısı ile gün sayısına ilişkin çeşit x gübre interaksiyonları Table 3. Variety $x$ manure interaction regarding number of days and average number of days regarding organic manure and cotton types used in trial

\begin{tabular}{|c|c|c|c|c|c|c|c|c|c|c|c|c|c|c|c|}
\hline \multirow{5}{*}{ 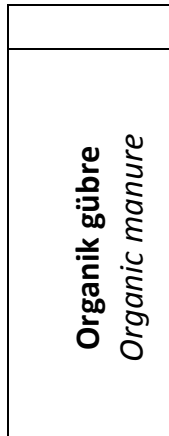 } & \multicolumn{15}{|c|}{ Gün sayısı (Number of days) } \\
\hline & \multicolumn{15}{|c|}{ Gelişme dönemleri ( Periods of development) } \\
\hline & \multirow{2}{*}{\multicolumn{3}{|c|}{$\begin{array}{l}\text { 1.Ekim-ilk Gerçek Yaprak } \\
\text { 1.Cultivation-first real leaf }\end{array}$}} & \multirow{2}{*}{\multicolumn{3}{|c|}{$\begin{array}{c}\text { 2.Ekim-ilk Taraklanma } \\
\text { 2.Cultivation- first } \\
\text { squaring }\end{array}$}} & \multirow{2}{*}{\multicolumn{3}{|c|}{$\begin{array}{c}\text { 3.Ekim-ilk Çiçek Açma } \\
\text { 3.Cultivation- first on } \\
\text { flowers } \\
\text { Çeşitler (Varieties) }\end{array}$}} & \multirow{2}{*}{\multicolumn{3}{|c|}{$\begin{array}{c}\text { 4.Ekim-illk Koza Açma } \\
\text { 4.Cultivation-first on bol } \\
\text { Çeşitler (Varieties) }\end{array}$}} & \multicolumn{3}{|c|}{$\begin{array}{l}\text { 5.Ekim-Hasat Olgunluğu } \\
\text { 5.Cultivation-Harvest of maturity }\end{array}$} \\
\hline & & & & & & & & & & & & & \multirow[b]{2}{*}{ 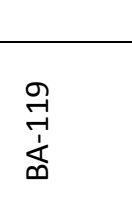 } & \multicolumn{2}{|c|}{ Çeşitler (Varieties) } \\
\hline & 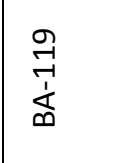 & $\frac{.00}{\frac{\pi}{0}}$ & 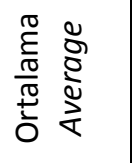 & 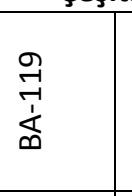 & $\frac{\frac{\pi}{\sigma}}{\frac{\pi}{0}}$ & 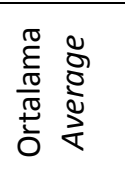 & 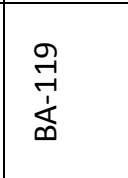 & $\underset{\frac{\pi}{\frac{\pi}{0}}}{\stackrel{\frac{\pi}{0}}{\cup}}$ & 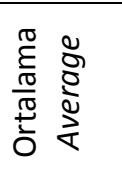 & $\underset{\substack{-\stackrel{1}{1}}}{\frac{1}{\infty}}$ & 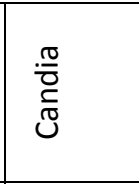 & 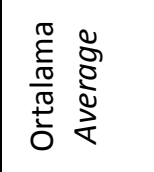 & & 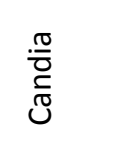 & 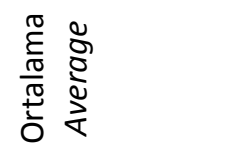 \\
\hline 1. (\#) & 15.50 & 19.37 & 17.43B & 36.87 & 52.25 & $44.56 \mathrm{~B}$ & 61.75 & 69.75 & $65.50 \mathrm{~B}$ & 113.12 & 125.62 & $119.37 C$ & 129.37 & 141.37 & $135.37 \mathrm{C}$ \\
\hline 2. (\#) & 15.62 & 19.25 & 17.43B & 36.50 & 52.50 & 44.50 & 61.75 & 71.25 & $66.50 \mathrm{~B}$ & 113.37 & 125.62 & $119.50 \mathrm{C}$ & 130.75 & 141.62 & 136.18B \\
\hline 3. (\#) & 15.37 & 19.00 & 17.18B & 37.12 & 52.37 & 44.75B & 61.25 & 70.12 & $65.68 \mathrm{~B}$ & 113.25 & 127.00 & $120.12 B C$ & 131.75 & 141.87 & $136.81 \mathrm{~B}$ \\
\hline 4. (\#) & 15.00 & 19.25 & 17.12B & 36.87 & 52.25 & 44.56B & 61.50 & 70.62 & $66.06 \mathrm{~B}$ & 116.37 & 127.62 & $122.00 \mathrm{~A}$ & 132.37 & 143.00 & $137.68 \mathrm{~A}$ \\
\hline 5. (\#) & 18.62 & 21.25 & $19.93 \mathrm{~A}$ & 40.12 & 54.12 & $47.12 \mathrm{~A}$ & 64.00 & 72.37 & $68.18 \mathrm{~A}$ & 115.62 & 126.62 & 121.12AB & 131.00 & 142.50 & 136.75B \\
\hline $\begin{array}{l}\text { Ortalama } \\
\text { Average }\end{array}$ & 15.94B & $19.56 \mathrm{~A}$ & 17.81 & $37.74 \mathrm{~B}$ & $52.70 \mathrm{~A}$ & 45.09 & 61.95B & $70.82 \mathrm{~A}$ & 66.38 & 114.35B & $126.50 \mathrm{~A}$ & 120.42 & 131.05B & $142.07 \mathrm{~A}$ & 136.56 \\
\hline LSD(\%5) & \multicolumn{3}{|c|}{$\begin{array}{c}0.65^{* *} \text { (Çeşit) (Variety) } \\
0.59^{* *} \text { (Gübre) (Manure) }\end{array}$} & \multicolumn{3}{|c|}{$\begin{array}{c}2.04^{* *} \text { (Çeşit) (Variety) } \\
1.08^{* *} \text { (Gübre) (Manure) }\end{array}$} & \multicolumn{3}{|c|}{$\begin{array}{c}1.85^{* *} \text { (Çeşit) (Variety) } \\
1.42^{* *} \text { (Gübre) (Manure) }\end{array}$} & \multicolumn{3}{|c|}{$\begin{array}{c}\text { 1.92** (Çeşit) (Variety) } \\
1.41 * * \text { (Gübre) (Manure) }\end{array}$} & \multicolumn{3}{|c|}{$\begin{array}{c}0.66 * * \text { (Çeşit) (Variety) } \\
0.77^{* *} \text { (Gübre) (Manure) }\end{array}$} \\
\hline CV(\%) & \multicolumn{3}{|c|}{4.72} & \multicolumn{3}{|c|}{3.39} & \multicolumn{3}{|c|}{3.02} & \multicolumn{3}{|c|}{1.64} & \multicolumn{3}{|c|}{0.79} \\
\hline
\end{tabular}

$(*): 0.05 ;\left(^{* *}\right): 0.01$ düzeyinde önemli fark bulunmaktadır.

(\#): 1. Biofarm gübresi (Biofarm manure). 2. Güvercin gübresi (Pigeon manure). 3. Biofarm gübresi + Mikrobiyal gübre (Biofarm manure + microbial manure).

4. Güvercin gübresi + Mikrobiyal gübre (Pigeon manure + microbial manure). 5. Kontrol (Control) 
Çizelge 4. Denemede kullanılan pamuk çeşitlerine ve organik gübrelere ilişkin ortalama gün-derece değerleri ile gün-derece değerlerine ilişkin çeşit x gübre interaksiyonları

Table 4. Variety manure interaction regarding day-degree values and average day-degree values regarding organic manure and cotton types used in trial

\begin{tabular}{|c|c|c|c|c|c|c|c|c|c|c|c|c|c|c|c|}
\hline & \multicolumn{15}{|c|}{ Gün-Derece $\left({ }^{\circ} \mathrm{C}\right)$ (Day-Degrees) } \\
\hline \multirow{4}{*}{ 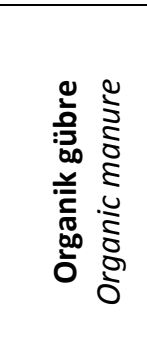 } & \multicolumn{15}{|c|}{ Gelişme dönemleri ( Periods of development) } \\
\hline & \multirow{2}{*}{\multicolumn{3}{|c|}{$\begin{array}{l}\text { 1.Ekim-ilk Gerçek Yaprak } \\
\text { 1.Cultivation-first real leaf } \\
\text { Cesitler (Varieties) }\end{array}$}} & \multirow{2}{*}{\multicolumn{3}{|c|}{$\begin{array}{l}\text { 2.Ekim-ilk Taraklanma } \\
\text { 2.Cultivation- first squaring } \\
\text { Çeşitler (Varieties) }\end{array}$}} & \multirow{2}{*}{\multicolumn{3}{|c|}{\begin{tabular}{|c|} 
3.Ekim-ilk Çiçek Açma \\
3.Cultivation-first on flowers \\
Çeşitler (Varieties) \\
\end{tabular}}} & \multirow{2}{*}{\multicolumn{3}{|c|}{$\begin{array}{l}\text { 4.Ekim-ilk Koza Açma } \\
\text { 4.Cultivation-first on bol } \\
\text { Çeşitler (Varieties) }\end{array}$}} & \multirow{2}{*}{\multicolumn{3}{|c|}{\begin{tabular}{|c|}
$\begin{array}{c}\text { 5.Ekim-Hasat Olgunluğu } \\
\text { 5.Cultivation-Harvest of maturity }\end{array}$ \\
Çeşitler (Varieties) \\
\end{tabular}}} \\
\hline & & & & & & & & & & & & & & & \\
\hline & 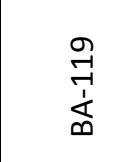 & 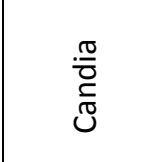 & 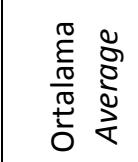 & 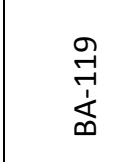 & $\frac{\frac{\pi}{\pi}}{\frac{\pi}{0}}$ & 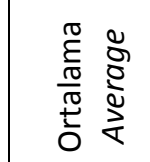 & 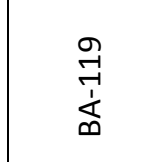 & $\begin{array}{l}\frac{\pi}{0} \\
\frac{\pi}{0} \\
\text { U }\end{array}$ & 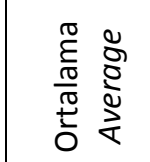 & 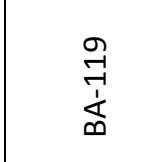 & $\begin{array}{l}\frac{\pi}{0} \\
\frac{\pi}{0} \\
\text { U }\end{array}$ & $\begin{array}{l}\frac{\pi}{2} \\
\frac{8}{0} \\
\frac{\pi}{\pi} \\
\frac{0}{2} \\
\frac{1}{2}\end{array}$ & $\underset{\substack{9 \\
\stackrel{1}{1}}}{\stackrel{1}{\infty}}$ & $\begin{array}{l}\frac{\pi}{0} \\
\frac{\pi}{0} \\
\text { U }\end{array}$ & 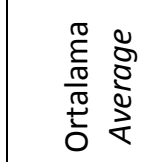 \\
\hline 1. (\#) & 103.12 & 134.15 & 118.63B & 308.13 & 492.06 & $400.10 B$ & 620.90 & 749.98 & $685.44 \mathrm{~B}$ & 1444.02 & 1616.91 & $1530.46 \mathrm{C}$ & 1673.00 & 1825.60 & $1749.30 \mathrm{C}$ \\
\hline 2. (\#) & 103.83 & 132.85 & 118.34B & 303.83 & 497.15 & 400.49B & 628.93 & 773.28 & 701.11B & 1445.87 & 1614.45 & $1531.16 \mathrm{C}$ & 1691.12 & 1828.72 & 1759.92B \\
\hline 3. (\#) & 102.48 & 130.52 & 116.50B & 310.18 & 492.85 & 401.51B & 621.57 & 753.93 & $687.75 \mathrm{~B}$ & 1447.25 & 1629.40 & 1537.32BC & 1704.35 & 1832.25 & 1768.31B \\
\hline 4. (\#) & 100.90 & 132.48 & 116.69B & 320.62 & 491.57 & 406.10B & 623.77 & 762.53 & 693.15B & 1494.17 & 1637.16 & $1565.66 \mathrm{~A}$ & 1713.40 & 1844.91 & 1779.15A \\
\hline 5. (\#) & 127.68 & 152.92 & 140.30A & 343.76 & 519.06 & $431.41 \mathrm{~A}$ & 660.63 & 787.70 & $724.16 \mathrm{~A}$ & 1483.85 & 1628.02 & $1555.93 \mathrm{AB}$ & 1691.91 & 1832.32 & 1762.11B \\
\hline $\begin{array}{l}\text { Ortalama } \\
\text { Average }\end{array}$ & 107.60B & $136.58 \mathrm{~A}$ & 122.09 & 317.31B & $498.54 \mathrm{~A}$ & 407.92 & 631.17B & $765.49 A$ & 698.33 & 1463.04B & $1625.19 A$ & 1544.11 & 1694.76B & $1832.77 \mathrm{~A}$ & 1763.76 \\
\hline LSD(\%5) & \multicolumn{3}{|c|}{$\begin{array}{c}\text { 5.46** (Çeşit) (Variety) } \\
4.98 * * \text { (Gübre) (Manure) }\end{array}$} & \multicolumn{3}{|c|}{$\begin{array}{l}\text { 17.11** (Çeşit) (Variety) } \\
\text { 9.33** (Gübre) (Manure) }\end{array}$} & \multicolumn{3}{|c|}{$\begin{array}{cc}\text { Ö.D. } & \text { (Çeşit) (Variety) } \\
\text { 20.77** (Gübre) (Manure) }\end{array}$} & \multicolumn{3}{|c|}{$\begin{array}{c}\text { 25.80** (Çeşit) (Variety) } \\
\text { 20.61** (Gübre) (Manure) }\end{array}$} & \multicolumn{3}{|c|}{$\begin{array}{l}\text { 9.86** (Çeşit) (Variety) } \\
\text { 9.10** (Gübre) (Manure) }\end{array}$} \\
\hline CV(\%) & \multicolumn{3}{|c|}{5.74} & \multicolumn{3}{|c|}{3.21} & \multicolumn{3}{|c|}{4.18} & \multicolumn{3}{|c|}{1.87} & \multicolumn{3}{|c|}{0.72} \\
\hline
\end{tabular}

$(*): 0.05 ;\left(^{* *}\right): 0.01$ düzeyinde önemli fark bulunmaktadır.

(\#): 1. Biofarm gübresi (Biofarm manure). 2. Güvercin gübresi (Pigeon manure). 3. Biofarm gübresi + Mikrobiyal gübre (Biofarm manure + microbial manure).

4. Güvercin gübresi + Mikrobiyal gübre (Pigeon manure + microbial manure). 5. Kontrol (Control) 
Bulgularımız, azot içerikli gübrelemenin verim ve kalite unsurlarında önemli düzeyde artış sağladığını belirten Gençer ve Oğlakçı (1983), uygun azot dozlarının bitkide verim artışı sağladığını belirten Bondada ve ark. (1996), azot içerikli gübrelemenin lif verimini arttırdığını belirten Phipps ve ark. (1997), Bacillus bakterisi ile uygulanan parsellerin verimi arttırdığını belirten Esitken ve ark. (2003), Bacillus türü bakterilerin bitkilerin tarımsal üretim ve ürün artışında direkt etkide bulunduğunu belirten Gardener (2004), organik gübre kullanımının topraktaki besin maddesi yarayışlı।ığı, toprağın su tutma kapasitesi, toprağın havalanması ve toprak yapısının iyileştirerek süreklilik sağladığını ve verimi arttırdıklarını belirten Jackson ve ark. (2003), bitki gelişmesini teşvik eden rizobakterilerin (PGPR) çimlenme oranı, kök gelişmesi, verim, yaprak alanı, protein oranı susuzluğa tolerans, kök ve gövde yapısını geliştirdiklerini belirten Çakmakçı (2005)'in bulguları ile kısmen veya tamamen uyum içinde olduğu belirlenmiştir. Ayrıca bulgularımız, Young ve ark. (1980); Wullschleger ve ark., (1990); Özbek ve ark. (2000), Mert ve Akışcan (2005)'in bulguları ile uyum içindedir. Çeşitlerin gelişme için ihtiyaç duydukları gün sayısı ve gün-derece yönünden farklı olmaları, genetik yapıları ve çevre faktörlerinin fizyolojik olaylara etkisinden kaynaklanmış olabilir. Bulgularımız, bitkileri kolonize olan bitki büyümesi ve verimi arttıran ve hastalıklara baskın olan Bacillus bakterilerinin bitki gelişimi ve verimine etkide bulunduklarını belirten Tozlu ve ark. (2012), 2002- 2006 yıllarında yaptıkları çalışmada Bacillus bakterilerinin bitki gelişimi ve verimine etkide bulunduklarını belirten Karlıdağ ve ark. (2007), 2013-2014 yıllarında, Erzurum koşullarında Bacillus subtilis ile tohum aşılama ve yapraklara püskürtme yolu ile yaptıkları çalışmada, bitki büyüme düzenleyicilerinin kontrol ile karşılaştırıldığında; bitki boyu, klorofil oranı, yaprak alanı ve sürgün miktarını arttırdığını belirten Turan ve ark. (2014)'nın bulguları ile uyum içindedir.

Çizelge 5 'ten Kütlü pamuk verimi ile gün sayısı ve gün-derece $\left({ }^{\circ} \mathrm{C}\right)$ değerleri arasında korelasyonlar incelendiğinde çeşitli sonuçlar ortaya çıkmaktadır. Çizelge $5^{\prime}$ den kütlü pamuk verimi $\left(\mathrm{kg} \mathrm{da}^{-1}\right)$ ile ekim-ilk gerçek yaprak gün sayısı arasında olumsuz ve önemli $\left(r=-0.5351^{* *}\right)$ bir korelasyon olduğu, tersi anlamda ekim-ilk gerçek yaprak gün sayısı düştüğünde (erkencilik sağlandığında) kütlü pamuk veriminde artış sağlanmıştır. Kütlü pamuk verimi $\left(\mathrm{kg} \mathrm{da}^{-1}\right)$ ile ekim- taraklanma başlangıcı gün sayısı arasında olumsuz $\left(r=-0.2270^{*}\right)$ ve önemli bir ilişki vardır. Ekimtaraklanma gün sayısı düştüğünde (erkencilik sağlandığında) kütlü pamuk veriminde (kg da $\left.{ }^{-1}\right)$ artış sağlanmıştır. Kütlü pamuk verimi (kg da ${ }^{-1}$ ) ile ekim- çiçeklenme başlangıcı gün sayısı arasında olumsuz ve önemli $\left(r=-0.2934^{* *}\right)$ bir korelasyon bulunmuştur. Tersi anlamında ekimçiçeklenme başlangıcı gün sayısı azaldığında (erkencilik sağlandığında) verimde artış olmuştur. Kütlü pamuk verimi $\left(\mathrm{kg} \mathrm{da}^{-1}\right)$ ile ilk açma gün sayısı arasında olumsuz ve önemli $\left(r=-0.2053^{*}\right)$ bir korelasyon olduğu, tersi anlamda ilk koza açma gün sayısı düştüğünde (erkencilik sağlandığında) verimde artış olduğu saptanmıştır. Kütlü pamuk verimi $\left(\mathrm{kg} \mathrm{da}^{-1}\right)$ ile ekim-hasat olgunluğu gün sayısı arasında olumsuz ve önemli ( $\left.r=-0.2511^{* *}\right)$ bir korelasyon olduğu, tersi anlamında ekimhasat olgunluğu gün sayısı azaldığında (erkencilik sağlandığında) kütlü pamuk veriminde artış olduğu saptanmıştır. Kütlü pamuk verimi $\left(\mathrm{kg} \mathrm{da}^{-1}\right)$ ile ekim ile ilk gerçek yaprak gün-derece $\left({ }^{\circ} \mathrm{C}\right)$ miktarı arasında olumsuz ve önemli $(r=-0.6669 * *)$ bir 
korelasyon olduğu, ekim-ilk gerçek yaprak gün-derece miktarı $\left({ }^{\circ} \mathrm{C}\right)$ azaldığında (erkencilik) kütlü pamuk verimi artmıştır. Yine kütlü pamuk verimi $\left(\mathrm{kg} \mathrm{da}^{-1}\right)$ ile taraklanma başlangıcı, çiçeklenme başlangıcı, koza açımı başlangıcı ve koza olgunluğu günderece $\left({ }^{\circ} \mathrm{C}\right)$ miktarları arasında aynı şekilde bir korelasyon vardır. Bu değerler azaldığında kütlü pamuk verimi artmıştır.

Çizelge 5. Kütlü pamuk verimi ile gün ve gün-derece $\left({ }^{\circ} \mathrm{C}\right)$ değerleri arasındaki korelasyon.

Table 5. The correlation between yield of cotton unseed and day and day-degree $\left({ }^{\circ} \mathrm{C}\right)$ values.

\begin{tabular}{|c|c|c|c|}
\hline $\begin{array}{l}\text { Değişken } \\
\text { Variable }\end{array}$ & $\begin{array}{l}\text { Değişkenler } \\
\text { Variables }\end{array}$ & $\begin{array}{l}\text { Korelasyon } \\
\text { Corelation }\end{array}$ & $\begin{array}{l}\text { Önem Düzeyi } \\
\text { Importance }\end{array}$ \\
\hline $\begin{array}{l}\text { Verim } \\
\text { Yield }\end{array}$ & $\begin{array}{c}\text { Ekim-ilk Gerçek Yaprak Gün Sayısı } \\
\text { (Cultivation-First Real Leaf Days) }\end{array}$ & $-0 .-0.5351^{* *}$ & $<0001$ \\
\hline $\begin{array}{l}\text { Verim } \\
\text { Yield }\end{array}$ & $\begin{array}{l}\text { Ekim-Taraklanma Gün Sayısı } \\
\text { (Cultivation-Squaring Days) }\end{array}$ & $-0.2270^{*}$ & 0.0126 \\
\hline $\begin{array}{l}\text { Verim } \\
\text { Yield }\end{array}$ & $\begin{array}{l}\text { Ekim-Çiçeklenme Gün Sayısı } \\
\text { (Cultivation-Flowering Days) }\end{array}$ & $-0.2934 * *$ & 0.0011 \\
\hline Verim & Ekim-illk Koza Açma Gün Sayısı & $-0.2053 *$ & 0.0245 \\
\hline Yield & (Cultivation-Firt Boll Openin Days) & & \\
\hline $\begin{array}{l}\text { Verim } \\
\text { Yield }\end{array}$ & $\begin{array}{l}\text { Ekim-Hasat Olgunluğu Gün Sayısı } \\
\text { (Cultivation-Harvest Maturity Days) }\end{array}$ & $-0.2511 * *$ & 0.0057 \\
\hline $\begin{array}{l}\text { Verim } \\
\text { Yield }\end{array}$ & $\begin{array}{c}\text { Ekim-illk Gerçek Yaprak Gün-Derece Değeri } \\
\text { (Cultivation-The First Real Leaf Day-Dagree Value) }\end{array}$ & $-0.6669 * *$ & $<0001$ \\
\hline $\begin{array}{l}\text { Verim } \\
\text { Yield }\end{array}$ & $\begin{array}{c}\text { Ekim-Taraklanma Gün-Derece Değeri } \\
\text { (Cultivation-Squaring Day-Dagree Value) }\end{array}$ & $-0.2655^{* *}$ & 0.0034 \\
\hline $\begin{array}{l}\text { Verim } \\
\text { Yield }\end{array}$ & $\begin{array}{l}\text { Ekim-Çiçeklenme Gün-Derece Değeri } \\
\text { (Cultivation-Flowering Day-Dagree Value) }\end{array}$ & $-0.4862 * *$ & $<0001$ \\
\hline $\begin{array}{l}\text { Verim } \\
\text { Yield }\end{array}$ & $\begin{array}{c}\text { Ekim-illk Koza Açma Gün-Derece Değeri } \\
\text { (Cultivation-First Boll Opening Day-Dagree Value) }\end{array}$ & $-0.3072 * *$ & 0.0006 \\
\hline $\begin{array}{l}\text { Verim } \\
\text { Yield }\end{array}$ & $\begin{array}{c}\text { Ekim-Hasat Olgunluğu Gün-Derece Değeri } \\
\text { (Cultivation-Harvest Maturity Day-Dagree Value) }\end{array}$ & $-0.2684^{* *}$ & 0.0030 \\
\hline
\end{tabular}

\section{Sonuçlar}

Bu çalışma sonucunda, pamuk bitkisinin farklı gelişme dönemleri için gerekli gün sayısı ve gün derece ünitesi gereksinimi, çeşidin genetik özelliklerine ve çevreye uyumuna, kullanılan organik gübrelere göre değiştiği belirlenmiştir. Çeşitlerin vejetasyon süresince ihtiyaç duydukları gün sayıları ve gün derece ünitesi ihtiyaçlarının bilinmesi çeşit seçiminde üreticilere kolaylık sağlayacaktır. Ayrıca kullanılan organik gübrelerin gün ve gün-derece ünitelerine etki ettikleri görülmüştür. Özellikle organik gübrelerle beraber kullanılan bakterilerin gün miktarını azalttığı ve gün- derece ünitelerini etkilediği görülmektedir.
Ekler

Bu çalışma 14089 nolu HÜBAK projesi olup 'Harran Ovası Organik Üretim Koşullarında, Organik ve Mikrobiyal Gübre Uygulamalarının Pamuk Çeşitlerinde (Gossypium hirsutum L.) Tarımsal ve Lif Kalite Özellikleri Üzerine Etkisi' konulu doktora tezinden alınmıştır.

\section{Kaynaklar}

Anonim, 1998. Statewide IPM Project, Division of Agriculture and Natural Resources, University of California. http://169.237.210.130/WEATHER/ddconc epts.html/Using. (Erişim tarihi: 01/04/2016). 
Anonim,

2016a. http://www.camli.com.tr/tr/urun/biofarm -humus-organik-gubre. (Erişim tarihi: 02.05.2016).

Anonim, 2016b. http://www.bioteknologie.com (Erişim tarihi: 01.04.2016)

Anonim, 2016c. Meteoroloji Bölge Müdürlüğü, Şanlıurfa Meteoroloji iı Müdürlüğü.

Bondada, B.R., Oosterhuıs, D.M., Norman, R.J., Baker, W.H., $1996 . \quad$ Canopy Photosynthesis, Growth, Yield and Boll $15 \mathrm{~N}$ Accumulation Under Nitrogen Stress in Cotton. American Society of Agronomy. (36): 127-133.

Çakmakçı, R., 2005. Bitki Gelişimini Teşvik Eden Rizobakterilerin Tarımda Kullanımı. Atatürk Üniversitesi Ziraat Fakültesi Dergisi, 36(1):97-107.

Esitken, A., Pirlak, L., Turan, M., Şahin, F., 2006. Effect of floral an foliar application of plant growth. Promoting rhizobacteria (PGPR) on yield, growth and nutrition of sweat cherry. Scientia Horticulturae 110: 324-327.

Gardener, M.C.B., 2004. Ecology of Bacillus and Paennibacillus spp. In Agricultural System. Department of Plant Pathology, The Ohio State University, OARDC, Wooster 44691. USA. Phytopathology, 1252-1258pp.

Gençer, O., Oğlakçı, M., 1983. Farklı Sıra Arası Uzaklığı ve Azot Gübrelemesinin, Pamuk Bitkisinin (G. hirsutum L.) Verim ve Kalite Unsurlarına Etkisi Üzerine Araştırmalar. Ç.Ü.Z.F. Yıllığı, Sayı: 3-4 Adana, 179-194s.

Halevy, J., Bazelet, M., 1989. Fertilizing for High Yield and Quality Cotton. IPI Bulletin 2. International Potash Institute. Bern/Switzerland, 52pp.

Jackson, L.E., Calderon, K.L., Steenwerth, K.M., Scow, K.M., Roltson, D.E., 2003. Responses of soil microbial processes and community structure to tillage events and implications for soil quality. Geoderma, 114:305-317.

Karlidag, H., Esitken, A., Turan, M., Sahin, F., 2007. Effects of root inoculation of plant growth promoting rhizobacteria (PGPR) on yield, growth and nutrient element contents of leaves of apple. Scientia Horticulturae. (114):16-20.
Özbek, N., Şahin, A., Ekşi, Y., 2000. Bazı pamuk çeşitlerinin gelişme dönemlerinde sıcaklık gereksinmelerinin gün-derece (GD) ünitesi olarak belirlenmesi. Nazilli Pamuk Araştırma Enstitüsü, Yayın No: 60:1-32s.

Mert, M., Akışcan, Y., 2005. Amik Ovası Koşullarında Bazı Pamuk (Gossypium hirsutum L.) Çeşitlerinin Gelişme Dönemlerine Göre Sıcaklık İsteklerinin Belirlenmesi. Türkiye VI. Tarla Bitkileri Kongresi. 5-9 Eylül 2005, Cilt I, 291-296s.

Phips, B.J., Stevens, W.E., Ward, J.N., Scales, T.V., 1997. The influence of Mepiquat Chloride (PIX) and Nitrogen Rate Upon the Maturity and Fiber Quality of Upland Cotton. Proceedings Beltwide Cotton Conferances. New Orleans January, 6-10pp.

Reddy, V.R., Reddy, K.R., Baker, D.N., 1991. Temperature Effect on Growth and Development of Cotton During the Fruiting Period. Agronomy Journal, 83: 211-217.

Reddy, K.R., Reddy, V.R., Hodges, H.F., 1992. Temperature effects on early season cotton growth and development. Agronomy Journal, 84: 229-237.

Tozlu, E., Karagöz, K., Babagil, G.E., Dizikısa, T., Kotan, R., 2012. Effect of Some Plant Growth Promoting Bacteria on Yield, Yield Components of Dry Bean (Phaseolus vulgaris L.cv. Aras 98). Atatürk Univ. Journal of Agricultural Faculty, 43(2):101106.

Turan, M., Ekinci, M., Yıldırım, E., Güneş, A., Karagöz, K., Kotan, R., Dursun, A., 2014. Plantgrowth-promoting rhizobacteria, improved growth nutrient, and hormone content of cabbage (Brassica oleracea) seedlings. Turkish Journal of Agriculture and foresty, 38:327-333.

Wullschleger, S.D., OosterhuIs, D.M., 1990. Canopy development and photosynthesis of cotton as influenced by nitrogen nutrition. Journal of Plant Nutrition, 9(14):1141-1154.

Young, E.F., Taylor, R.M., Peterson, H.D., 1980. Day-degree unit sand time in relation to vegetative development and fruiting for three cultivars of cotton. Crop. Science, 20: 370-374. 